\title{
PERATURAN DAERAH BERMUATAN SYARIAT ISLAM DITINJAU DARI PRINSIP DEMOKRASI KONSTITUSIONAL
}

\author{
Fuqoha \\ Universitas Serang Raya | Jl. Raya Serang-Cilegon Km. 5, Serang \\ fuqoha23@gmail.com
}

\begin{abstract}
In managing a local government or municipality, regulation is a must. Forms of regulatory framework in this context is bylaw. In today's democratic Indonesia, local government has authority to form and implement bylaw according to local needs and values. Including bylaw on sharia. Among the purpose of bylaw is maintaining order. From the perspective of constitutional democracy, sharia bylaws is the right of each local government and community as long as not contradictory to the Constitution. Liberty to enact certain bylaw shows a working democracy. Therefore, sharia bylaw is an indication of ideal democracy, not threat to democracy.
\end{abstract}

Key Words: bylaws, sharia, constitutional democracy

Abstrak: Dalam penyelenggaraan pemerintahan daerah, perlu aturan hukum sebagai landasan dalam melaksanakan segala urusan pemerintahan daerah. Bentuk pengaturan dalam pemerintahan daerah ialah peraturan daerah. Konsepsi demokrasi memberikan kewenangan pada setiap daerah untuk membentuk dan memberlakukan peraturan daerah sesuai dengan nilai-nilai kearifan lokal. Di antara nilai-nilai kearifan lokal dalam muatan peraturan daerah adalah syariat Islam. Tujuan dibentuknya peraturan daerah di antaranya adalah untuk memelihara ketertiban hukum (rechtsorde) sesuai dengan cita atau kekhasan masyarakat daerah. Ditinjau dari prinsip demokrasi konstitusional, peraturan daerah bermuatan syariat Islam merupakan hak bagi setiap daerah dan masyarakat daerah sesuai dengan kesepakatan masyarakat (resultante) selama tidak bertentangan dengan konstitusi. Muatan syariat Islam dalam peraturan daerah dibatasi oleh konstitusi dalam prinsip demokrasi konstitusional. Kebebasan dalam memberikan muatan dalam suatu peraturan daerah, menunjukkan konsep demokrasi yang dianut bangsa Indonesia terlaksana sesuai dengan ketetapan pada konstitusi, sehingga pemberlakuan peraturan daerah bermuatan syariat Islam 
merupakan cita demokrasi dan bukan merupakan ancaman bagi demokrasi.

Kata Kunci: Peraturan Daerah, syariat Islam, demokrasi konstitusional

\section{Pendahuluan}

Sistem ketatanegaraan Indonesia menegaskan dalam rangka penyelenggaraan negara berasaskan pada prinsip otonomi daerah bahwa negara Indonesia dibagi atas daerah-daerah propinsi dan kabupaten/kota. Ketentuan konstitusional tersebut dirumuskan dalam rangka pemenuhan kepastian hukum penyelenggaraan pemerintahan daerah. Dengan diaturnya ketentuan terkait pemerintahan daerah, maka pemerintah daerah memiliki kewenangan untuk mengurusi urusan pemerintahan daerah sesuai kewenangan yang diatur dalam undang-undang.

Pemerintahan daerah merupakan penyelenggaraan pemerintahan daerah menurut asas otonomi dan tugas pembantuan dengan prinsip otonomi seluas-luasnya dalam sistem dan prinsip Negara Kesatuan Republik Indonesia. ${ }^{1}$ Untuk melaksanakan prinsip otonomi daerah, diperlukan penyelenggara pemerintahan daerah yang melaksanakan urusan pemerintahan dan kepentingankepentingan masyarakat daerah. Penyelenggara daerah terdiri atas Kepala Daerah, Dewan Perwakilan Rakyat Daerah (DPRD) serta Perangkat Daerah yang memiliki tugas dan fungsi untuk menyelenggarakan pemerintahan.

Indonesia merupakan negara hukum, sehingga sebagai negara hukum yang diatur dalam Konstitusi Negara Republik Indonesia dalam menyelenggarakan otonomi daerahnya, maka pemerintah daerah diberikan kewenangan guna membentuk Peraturan Daerah

\footnotetext{
I Asas otonomi yaitu prinsip dasar penyelenggaraan pemerintahan daerah berdasarkan otonomi daerah. Otonomi daerah adalah hak, wewenang dan kewajiban daerah otonom untuk mengatur dan mengurus sendiri urusan pemerintahan dan kepentingan masyarakat setempat dalam sistem Negara Kesatuan Republik Indonesia. Tugas pembantuan ialah penugasan dari pemerintah pusat kepada daerah otonom untuk melaksanakan sebagian urusan pemerintahan yang menjadi kewenangan pemerintah pusat atau dari pemerintah provinsi kepada daerah kabupaten/kota untuk melaksanakan sebagian urusan pemerintahan yang menjadi kewenangan pemerintah provinsi. Undang-Undang Nomor 23 Tahun 2014 tentang Pemerintah Daerah.
} 
(PERDA). Pembentukan peraturan perundang-undangan merupakan bagian dari kepastian hukum bagi pemerintah dalam bernegara. Kewenangan pembentukan peraturan daerah telah diatur melalui Undang-Undang No. 12 Tahun 2011 tentang pembentukan perundang-undangan. Keberadaan suatu peraturan daerah merupakan bagian dari kepastian hukum dan penjabaran terhadap kebijakan maupun peraturan perundang-undangan yang berada di tingkat pusat atau undang-undang yang lebih tinggi. Dengan adanya peraturan daerah, maka prinsip penyelenggaran pemerintahan daerah sesuai dengan semangat hukum, yang mengkonsepsi sebagai negara hukum.

Dilihat dari segi sosial budaya, negara Indonesia memiliki keberagaman budaya yang sangat luas. Indonesia memiliki keberagaman suku bangsa, budaya serta agama yang memunculkan semboyan Bhinneka Tunggal Ika bahwa walaupun berbeda-beda suku bangsa, budaya dan agama, kita tetap satu sebagai bangsa Indonesia. Keberagaman budaya, suku bangsa serta agama tentu mempengaruhi dalam hal penyelenggaraan daerah dalam prinsip otonomi daerah. Selain itu, negara Indonesia merupakan salah satu negara dengan mayoritas muslim yang tersebar di setiap daerah yang ada di Indonesia. Dengan prinsip otonomi daerah, maka setiap daerah memiliki peluang untuk mengatur penyelenggaran pemerintahan daerah sesuai kehendak dan keyakinan masyarakat. Salah satu hal yang menjadi perdebatan adalah terkait produk hukum yang bermuatan atau berisi nilai-nilai keyakinan atau nilai-nilai agama.

Produk hukum yang dapat dibentuk oleh pemerintah daerah yaitu Peraturan Daerah atau Peraturan Kepala Daerah yang disesuaikan dengan muatan-muatan lokal sesuai kebutuhan masyarakat lokal, selama tidak bertentangan dengan peraturan perundang-undangan yang lebih tinggi. Dalam proses pembentukan peraturan daerah, dimungkinkan masyarakat di daerah memberikan masukan mengenai ketentuan dalam sebuah peraturan derah. 
Konsepsi otonomi daerah sesuai amanat konstitusi, maka pemerintah pusat memberikan sebagian kekuasaan kepada daerah untuk melaksanakan kekuasaan di daerah yang sering disebut dengan istilah desentralisasi. Desentralisasi yaitu penyerahan urusan pemerintahan oleh pemerintah pusat kepada daerah otonom dalam asas otonomi. ${ }^{2}$ Asas otonomi adalah prinsip dasar penyelenggaraan pemerintahan daerah berdasarkan otonomi daerah.

Dalam prinsip otonomi daerah, selain asas desentralisasi terdapat asas dekonsentrasi, yaitu pelimpahan sebagian urusan pemerintahan yang menjadi kewenangan pemerintah pusat kepada gubernur sebagai wakil pemerintah pusat, kepada instansi vertikal di wilayah tertentu, dan/atau kepada gubernur dan bupati/walikota sebagai penanggungjawab urusan pemerintahan umum. Dengan prinsip desentralisasi dalam penyelenggaraan negara memberikan gambaran bahwa pemerintahan sangat demokratis.

Prinsip demokrasi merupakan bagian yang tak terpisahkan dalam penyelenggaraan otonomi daerah. Demokrasi memberikan setiap daerah kebebasan untuk mengatur dan menyelenggarakan pemerintahan daerah sesuai kehendak masyarakat daerah. Demokrasi dalam konsteks daerah memberikan kebebasan kepada setiap daerah untuk mengembangkan diri sesuai kehendaknya. Dengan demikian, prinsip demokrasi memberikan hak dan kebebasan kepada daerah untuk mengurus dan melaksanakan kehendak daerah sesuai konsepsi otonomi daerah. Demokrasi yang dilaksanakan di Indonesia yaitu demokrasi konstitusional, di mana prinsip demokrasi dibatasi oleh konstitusi.

Penyelenggaraan daerah melalui asas otonomi merupakan bagian dari prinsip demokrasi konstitusional, karena pelaksanaan otonomi daerah telah diatur dalam konstitusi negara dan dituangkan dalam undang-undang tentang pemerintahan daerah. Pada pelaksanaannya, pemerintah daerah berhak untuk 
melaksanakan segala urusan pemerintahan sesuai dengan ketentuan perundang-undangan untuk memajukan daerahnya dalam prinsip demokrasi konstitusional.

Dalam penyelenggaraan pemerintahannya, demokrasi memberikan kebebasan pada pemerintah daerah untuk menyelenggarakan daerahnya sesuai dengan aspirasi masyarakat di daerahnya. Pemerintah daerah, berkenaan dengan pengaturanpengaturan bagi masyarakat di daerahnya, disesuaikan dengan kondisi sosial, budaya serta agama. Oleh karena itu, ketika suatu daerah memiliki kondisi sosial dan keyakinan yang dimiliki oleh mayoritas di daerah akan berpengaruh dalam penyusunan dan pembuatan peraturan-peraturan di daerah.

Indonesia merupakan negara dengan mayoritas muslim, dengan demikian daerah dengan masyarakat yang memiliki keyakinan Islam sudah tentu akan berpengaruh terhadap produkproduk kebijakan maupun produk hukum yang bernuansa syariat Islam. Demokrasi memberikan kebebasan kepada pemerintah daerah untuk menyelenggarakan hal tersebut, selama tidak bertentangan dengan prinsip demokrasi secara menyeluruh. Syariat Islam sering diartikan dalam bentuk pengamalan nilai agama Islam secara keseluruhan. Namun dalam konsteks berbangsa dan bernegara, syariat Islam cenderung digunakan sebagai bentuk fikih atau sumber-sumber hukum dalam kehidupan bernasyarakat sesuai nilai-nilai Islam.

Pada kenyataannya, lahirnya produk-produk kebijakan pemerintah daerah, khususnya produk hukum bermuatan syariat Islam, dinilai oleh sebagian masyarakat bertentangan dengan prinsip demokrasi bahwa kebebasan setiap orang tidak dibenarkan melanggar kebebasan orang lainnya. Pertentangan tersebut dikarenakan di setiap daerah tentu ada mayoritas dan minoritas, sehingga mengakibatkan pro dan kontra dari kelompok minoritas bahkan dari sebagian masyarakat muslim sendiri. Namun demikian, dalam perspektif ilmu hukum bahwa hukum timbul dari perilaku masyarakat yang kemudian disepakati oleh masyarakat 
untuk dijadikan sebuah aturan bermasyarakat. Daerah dengan mayoritas masyarakat muslim memiliki peluang untuk menciptakan aturan-aturan sesuai dengan keyakinan Islam atau peraturan daerah yang bermuatan syariat Islam.

Berdasarkan uraian di atas, maka dalam artikel ini dibahas permasalahan tentang peraturan daerah bermuatan syari'at Islam ditinjau dari prinsip demokrasi konstitusional dengan pendekatan yuridis normatif sebagai suatu pendekatan yang mengkonsepsi hukum sebagai norma, kaidah, asas atau dogma-dogma melalui pengorganisasian atau klasifikasi data secara sistematis dengan menganalisis peraturan-peraturan yang berlaku. ${ }^{3}$

\section{Pembentukan Peraturan Daerah dalam Sistem Ketatanegaraan Indonesia}

Sistem ketatanegaraan Indonesia mengatur mengenai prinsip otonomi daerah yang memberikan kewenangan kepada daerah untuk melaksanakan dan menyelenggarakan urusan pemerintahan di daerahnya sendiri. Dengan demikian negara memberikan jaminan kepada penyelenggara negara di daerah untuk dapat menyelenggarakan pemerintahan. Konsepsi otonomi daerah sesusai sistem ketatanegaraan Indonesia memiliki tujuan guna menciptakan ketertiban dan keteraturan, serta memberikan pelayanan yang merata terhadap masyarakat di daerah.

Konsepsi pemikiran pembentukan pemerintahan daerah dalam prinsip otonomi daerah mengandung makna bagi eksistensi daerah otonom dalam penyelenggaran pemerintahan daerah. Pertama, prinsip otonomi daerah menggunakan prinsip otonomi seluas-luasnya yang berarti bahwa daerah memiliki kewenangan untuk membentuk kebijakan daerah, untuk memberi pelayanan, prakarsa dan pemberdayaan masyarakat. Kedua, prinsip otonomi daerah menggunakan prinsip otonomi yang nyata dan

${ }^{3}$ Soerjono Soekanto dan Sri Mamudji, Penelitian Hukum Normatif, (Jakarta: Rajawali Press, 2006), 14-15. 
bertanggungjawab yang berarti pemerintah dilaksanakan sesuai dengan kewenangan dan potensi kekhasan daerah. ${ }^{4}$

Otonomi daerah adalah hak, wewenang, dan kewajiban daerah otonom untuk mengatur dan mengurus sendiri urusan pemerintahan dan kepentingan masyarakat setempat dalam sistem Negara Kesatuan Republik Indonesia. ${ }^{5}$ Dengan demikian, menjadi suatu kewajiban bagi daerah untuk membangun daerah dan menciptakan kesejahteraan bagi masyarakat daerah sesuai dengan kultur dan karakteristik daerah. Konsepsi otonomi daerah merupakan bagian dari pengakuan terhadap daerah yang diamanatkan dalam undang-undang dasar 1945.

Dalam undang-undang dasar 1945 tentang Otonomi Daerah Pasal 18 Ayat (2) menyebutkan pemerintah daerah provinsi, pemerintah daerah kabupaten dan kota mengatur dan mengurus sendiri urusan pemerintahan menurut asas otonomi dan tugas pembantuan. Berkenaan dengan kewenangan dalam membentuk peraturan perundang-undangan dijamin melalui Pasal 18 Ayat (6) bahwa pemerintah daerah berhak menetapkan peraturan daerah dan peraturan-peraturan lain untuk melaksanakan otonomi dan tugas pembantuan.

Kewenangan pemerintah daerah dalam pembentukan dan/atau penetapan suatu peraturan daerah dalam sistem ketatanegaraan Indonesia adalah dalam rangka memenuhi kebutuhan masyarakat akan kepastian hukum. Penetapan peraturan daerah diakui sebagai salah satu jenis peraturan perundang-undangan, bahwa jenis dan hierarki perundangundangan di Indonesia antara lain: a) Undang-Undang Dasar Negara Republik Indonesia 1945; b) Ketetapan Majelis Permusyawaratan Rakyat; c) Undang-Undang/Peraturan Pemerintah Pengganti Undang-Undang; d) Peraturan Pemerintah;

${ }^{4}$ Siswanto Sunarno, Hukum Pemerintahan Daerah di Indonesia, (Jakarta: Sinar Grafika, 20I2), 8.

${ }_{5}^{5}$ Undang-Undang No. 23 Tahun 20 I 4 tentang Pemerintahan Daerah, Bab I Pasal I Ayat (6). 
e) Peraturan Presiden; f) Peraturan Daerah Provinsi; dan g) Peraturan Daerah Kabupaten/Kota. ${ }^{6}$

Dengan penyelenggaraan pemerintahan daerah seluasluasnya diharapkan dapat meningkatkan pelayanan publik yang merata serta meningkatkan kesejahteraan bagi masyarakat di daerah. Mahfud MD menyampaikan salah satu visi otonomi daerah adalah untuk membangun harmoni sosial sekaligus memelihara nilai-nilai lokal yang kondusif.7 Dengan demikian, untuk menciptakan ketertiban hukum yang harmonis dalam pergaulan hidup masyarakat daerah harus dilandaskan pada cita hukum yang berlandaskan nilai-nilai dan karakteristik masyarakat daerah. Sebagai negara hukum, maka segala tindakan dan perbuatan dilaksanakan berdasarkan pada aturan hukum. Oleh karena itu, melalui undang-undang No. 12 Tahun 2011 tentang Pembentukan Peraturan Perundang-undangan, salah satu bentuk peraturan perundang-undangan adalah Peraturan Daerah (PERDA).

Adanya peraturan daerah merupakan bagian dalam rangka penyelenggaraan pemerintahan yang menjadi urusan-urusan daerah dalam rangka tertib hukum. Dengan dibentuknya suatu peraturan daerah, maka terdapat kepastian hukum yang merupakan perwujudan sebagai negara hukum yang dianut negara Indonesia. Di antara tujuan dibentuknya peraturan daerah adalah sebagai pemenuhan hukum bagi masyarakat daerah dalam penyelenggaraan pemerintahan daerah.

Peraturan daerah oleh Jimly Asshiddiqie disamakan dengan undang-undang lokal atau local wet (local legislation) yang dibentuk oleh pemerintah lokal dan berlaku di wilayah satuan pemerintah lokal. ${ }^{8}$ Dalam prinsip demokrasi, maka pembentukan undangundang lokal atau peraturan daerah mengakomodir aspirasi masyarakat daerah sesuai nilai-nilai kearifan lokal. Nilai-nilai

\footnotetext{
${ }^{6}$ Undang-Undang No. 12 Tahun 201 I tentang Pembentukan Peraturan Perundang-undangan. Bab III Pasal 7 Ayat (I).

7 Alwi Bik, "Peraturan Daerah Syariah dalam Bingkai Otonomi Daerah", Al-Daulah: Jurnal Hukum dan Perundangan Islam, Volume 3, Nomor 2, (Oktober 20 I3), 282.

$8 \mathrm{lbid}$.
}

\begin{tabular}{l|l}
8 & $\begin{array}{l}\text { al-Daulah } \\
\text { Vol. 8. No. 1. April } 2018\end{array}$
\end{tabular} 
kearifan lokal merupakan bagian hidup yang tak terpisahkan dalam kehidupan bermasyarakat yang diperlihatkan melalui perilaku masyarakat. ${ }^{9}$

Berdasarkan sistem ketatanegaraan Indonesia, pembentukan atau penyusunan peraturan daerah disesuaikan dengan kebutuhan yang diatur sesuai dengan Peraturan Presiden No. 87 Tahun 2014 tentang Peraturan Pelaksana Undang-Undang No.12 Tahun 2011 tentang Pembentukan Peraturan Perundang-Undangan. Dalam ketentuan perundang-undangan tentang pembentukan undangundang, bahwa pembentukan peraturan daerah harus sesuai dengan Program Legislasi Daerah (PROLEGDA) yang merupakan instrumen perencanaan program pembentukan peraturan daerah provinsi atau peraturan daerah kabupaten/kota yang disusun secara terencana, terpadu dan sistematis.

Pembentukan atau penyusunan peraturan daerah, diatur sesuai Peraturan Presiden No. 87 Tahun 2014 Pasal 38 menyebutkan Rancangan Peraturan Daerah harus didasarkan pada: a) perintah peraturan perundang-undangan yang lebih tinggi; b) rencana pembangunan daerah; c) penyelenggaraan otonomi daerah dan tugas pembantuan; dan d) aspirasi masyarakat daerah. Dalam upaya mengatur urusan pemerintahan daerah, masyarakat memiliki kesempatan untuk memberikan pendapat dan/atau kritik terhadap pemerintahan terkait pembentukan dan penyusunan peraturan daerah. Sehingga lahirnya suatu peraturan daerah diharapkan sesuai dengan aspirasi masyarakat dan keyakinan hidup masyarakat.

Penyusunan peraturan perundang-undangan telah diatur dalam ketentuan Undang-Undang No.12 Tahun 2011 Pasal 96 Ayat (1) bahwa masyarakat berhak memberikan masukan secara lisan dan/atau tertulis dalam pembentukan peraturan perundangundangan. Adanya ketentuan tersebut dimaksudkan untuk memberikan kesempatan kepada masyarakat untuk terlibat dalam

9 Ibid., 283. 
memberikan muatan atau substansi peraturan hukum sesuai dengan kebutuhan dan kepentingan masyarakat.

Peraturan daerah dibentuk sesuai dengan kebutuhan pemerintah daerah dan kondisi sosial yang terjadi di daerah. Oleh karena itu, sesuai dengan Undang-Undang No. 12 Tahun 2011 dalam Pasal 14 bahwa muatan materi peraturan daerah provinsi dan peraturan daerah kabupaten/kota berisi materi muatan dalam rangka penyelenggaraan otonomi daerah dan tugas pembantuan serta menampung kondisi khusus daerah dan/atau penjabaran lebih lanjut peraturan perundang-undangan yang lebih tinggi. Dalam pelaksanaan penyelenggaraan daerah, terdapat beberapa daerah berdasarkan undang-undang diberikan kekhususan. Namun demikian, kewenangan daerah yang tidak diberikan otonomi khusus tidak dibatasi dalam menyelenggarakan daerah sesuai dengan kondisi sosial dan budaya daerahnya masing-masing.

Berasumsi pada pandangan K.C Wheare tentang konstitusi bahwa peraturan perundang-undangan sebagai bagian yang merupakan resultante (produk kesepakatan) sesuai dengan situasi politik, ekonomi, sosial dan budaya yang mempengaruhi terbentuknya peraturan perundang-undangan. ${ }^{10}$ Dengan memposisikan peraturan daerah sebagai produk kesepakatan, maka hal tersebut merupakan kesepakatan antara pemerintah daerah dengan masyarakat di daerah untuk menghasilkan produk hukum sesuai kondisi dan kebutuhan daerah. Dengan adanya konsepsi otonomi daerah dan konsepsi negara hukum, maka untuk mengatur segala urusan yang berkaitan dengan penyelenggaraan daerahnya diperlukan aturan-aturan yang dimuat dalam peraturan daerah yang disesuaikan dengan kebutuhan masyarakat dan pemerintah daerah. 


\section{Peraturan Daerah Bermuatan Syariat Islam dan Prinsip Demokrasi Konstitusional}

Prinsip demokrasi merupakan ciri dari konsep negara hukum, menurut J. Stahl dan Kant sering disebut dengan istilah rechtsstaat sedangkan A.V Dicey menyebutnya dengan istilah rule of law.11 Berlandaskan pada konsepsi negara hukum, baik konsepsi rechtsstaat maupun rule of law, maka hukum menjadi landasan yang menjadi kepastian hukum dan perlindungan hukum yang menjamin hak asasi manusia dalam pergaulan hidup bermasyarakat dalam prinsip demokrasi konstitusional. Robert Rienow menyebutkan bahwa suatu pemerintahan otonom merupakan ajang latihan berdemokrasi, bahkan lebih dari itu merupakan esensi demokrasi. ${ }^{12}$

Demokrasi dapat dipahami melalui dua pendekatan, pendekatan secara normatif dan pendekatan secara empirik:

Demokrasi secara normatif dipahami sebagai suatu yang secara ideal hendak dilakukan atau diselenggarakan oleh negara yang diterjemahkan dalam konstitusi. Sedangkan demokrasi secara empirik dipahami sebagai perwujudan kehidupan politik praktis, yang menggambarkan bagaimana suatu sistem politik dalam memberikan ruang bagi masyarakat untuk terlibat dalam pemerintahan. ${ }^{13}$

Prinsip demokrasi konstitusional dalam penyelenggaraan negara menggambarkan bahwa kekuasaan pemerintahan dan kebebasan masyarakat dibatasi oleh konstitusi. Prinsip demokrasi memberikan ruang atau kebebasan bagi seluruh unsur negara, baik bagi pemerintah maupun bagi rakyat, untuk melaksanakan tindakan-tindakan sesuai dengan kepentingan maupun kebutuhan dalam bernegara. Akan tetapi dalam konsepsi negara hukum, kebebasan tersebut perlu dibatasi oleh konstitusi agar kebebasan

\footnotetext{
IJ Jimly Asshiddiqie, Hukum Tata Negara dan Pilar-Pilar Demokrasi, Edisi Kedua, Jakarta: Sinar Grafika, 2012), 130.

12 Utang Rosidin, Otonomi Daerah dan Desentralisasi, (Bandung: Pustaka Setia, 20 I0), 39.

13 Fuqoha, "Etika Rangkap Jabatan dalam Penyelenggaraan Negara ditinjau dalam Prinsip Demokrasi Konstitusional", Sawala: Jurnal Administrasi Negara, Volume 3, Nomor 3, (20 I 5), 33.
} 
yang diberikan tidak melebihi batas. ${ }^{14}$ Pembatasan kekuasaan atau kebebasan dalam prinsip demokrasi konstitusional telah diatur dalam Undang-Undang Dasar 1945 bahwa:

(1) Setiap orang wajib menghormati hak asasi manusia orang lain dalam tertib kehidupan bermasyarakat, berbangsa dan bernegara; (2) Dalam menjalankan hak dan kebebasannya, setiap orang wajib tunduk kepada pembatasan yang ditetapkan dengan undang-undang dengan maksud semata-mata untuk menjamin pengakuan serta penghormatan atas hak dan kebebasan orang lain dan untuk memenuhi tuntutan yang adil sesuai dengan pertimbangan moral, nilai-nilai agama, keamanan, dan ketertiban umum dalam suatu masyarakat yang demokratis. ${ }^{15}$

Konsep rechtstaat dan rule of law menempatkan konstitusi sebagai landasan bernegara. Konstitusi menjadi dasar hukum tertulis yang paling tinggi dalam konsep negara hukum, sehingga konstitusi menjadi rujukan dasar atau sumber hukum dalam berbagai tindakan bernegara. Selain menjamin prinsip demokrasi, konstitusi juga mengatur prinsip otonomi daerah sebagai salah satu materil dalam konstitusi Indonesia terhadap penyelenggaraan atau pelaksanaannya pemerintah daerah yang diatur dalam UndangUndang Dasar 1945 Pasal 18, Pasal 18A dan Pasal 18B.

Konsepsi otonomi daerah memberikan kesempatan dan kekuasaan untuk mengatur serta mengurus urusan pemerintahan dan kepentingan masyarakat setempat. Terdapat beberapa unsur terbentuknya daerah otonom yaitu unsur batas wilayah, unsur pemerintahan dan unsur masyarakat. ${ }^{16}$

Pada prinsipnya, otonomi daerah memberikan kebebasan bagi pemerintah daerah untuk memelihara dan memajukan kepentingan khusus daerah dengan keuangan sendiri, menentukan aturan hukum sendiri serta pemerintahan sendiri. ${ }^{17}$ Dalam

\footnotetext{
14 Miriam Budiardjo, Dasar-Dasar Ilmu Politik, (Jakarta: Gramedia Pustaka Utama, 2008), 107.

15 Undang-Undang Dasar 1945. BAB XA Hak Asasi Manusia Pasal 28J Ayat (2).

${ }_{16}$ Siswanto Sunarno. Hukum Pemerintahan.. 6.

17 Nur Syafa'at, "Pelayanan Kesehatan di Daerah Otonom Baru (Studi Kasus di Kabupaten Tana Tidung, Kalimantan Timur)", Sawala: Jurnal Administrasi Negara, Volume 4, Nomor I, (2016), 31.
}

\begin{tabular}{l|l}
12 & $\begin{array}{l}\text { al-Daulah } \\
\text { Vol. 8. No. 1. April } 2018\end{array}$
\end{tabular} 
penyelenggaraan pemerintahan daerah melalui asas otonomi maupun pembantuan memerlukan landasan dalam mewujudkan tujuan masyarakat daerah. Prinsip negara hukum memberikan kewajiban bahwa setiap pelaksanaan atau penyelenggaraan negara, baik oleh pemerintah pusat maupun pemerintah daerah, harus didasarkan aturan hukum. Tujuan suatu negara di antaranya adalah untuk memelihara ketertiban hukum (rechtsorde), sehingga negara membutuhkan hukum yang dijalankan dan ditegakkan oleh negara. ${ }^{18}$

Konsep rechtsorde dalam prinsip otonomi daerah adalah dalam rangka mewujudkan ketertiban hukum bagi masyarakat daerah, maka pemerintah daerah membutuhkan peraturan perundangundangan sebagai landasan guna mengatur pergaulan hidup di masyarakat daerah. Karakteristik hukum dalam konsep otonomi daerah dipengaruhi oleh faktor atau unsur wilayah yang merupakan suatu kesatuan masyarakat hukum, dimana batas wilayah akan menentukan suatu kepastian hukum, baik bagi pemerintah daerah maupun masyarakat, dalam melakukan interaksi hukum. Selain dipengaruhi oleh faktor wilayah, karakteristik hukum di daerah akan dipengaruhi juga oleh faktor masyarakat yang memiliki tradisi dan keyakinan masyarakat.

Pengaturan pembentukan peraturan daerah yang mengakomodasi aspirasi masyarakat dapat memuat materi muatan lokal dan asas yang tumbuh dan berkembang dalam masyarakat sesuai dengan ketentuan peraturan perundang-undangan serta tidak bertentangan dengan prinsip Negara Kesatuan Republik Indonesia. Dalam teknisnya, masyarakat juga diberikan hak untuk memberikan masukan materi atau muatan, baik secara tertulis maupun secara lisan. ${ }^{19}$

\footnotetext{
18 Majda El-Muhtaj. Hak Asasi Manusia dalam Konstitusi Indonesia: dari UUD 1945 sampai dengan Amandemen UUD 1945 Tahun 2002, (Jakarta: Kencana, 2007), 20.

${ }^{19}$ Undang-Undang No. 23 Tahun 2014 tentang Pemerintahan Daerah. Bab IX Pasal 236 Ayat (4) dan Pasal 237 Ayat (I) dan (3).
} 
Negara Indonesia merupakan negara dengan mayoritas muslim bahkan menjadi negara dengan jumlah penduduk muslim terbesar di dunia. Berlandaskan pada prinsip otonomi daerah, memberikan peluang dalam rangka formalisasi atau penerapan syariat Islam bagi masyarakat daerah. Dari pemikiran Wheare bahwa peraturan perundang-undangan sebagai resultante (produk kesepakatan), yang berarti bahwa pemerintah daerah dapat menjadikan nilai-nilai agama Islam atau syariat Islam sebagai landasan dalam penyusunan dan pembentukan peraturan daerah. Menciptakan aturan-aturan yang berlandaskan pada nilai-nilai keyakinan atau agama yang menjadi ciri atau karakteristik dari kearifan lokal daerah merupakan bagian prinsip demokrasi konstitusional. Hal tersebut dijamin melalui Undang-Undang Dasar 1945 Pasal 28I Ayat (3) bahwa identitas budaya dan hak masyarakat tradisional dihormati selaras dengan perkembangan zaman dan peradaban.

Upaya pemberlakuan nilai-nilai Islam dalam bentuk kepastian hukum seperti peraturan daerah bermuatan syariat Islam sangat dimungkinkan dalam konsepsi otonomi daerah di Indonesia. Pembentukan peraturan daerah bermuatan nilai-nilai Islam didukung oleh kehendak masyarakat (resultante). Selain itu, terdapat beberapa faktor pendukung, antara lain:

Pertama, terdapatnya partai-partai politik yang berideologikan Islam yang menjadi wadah aspirasi masyarakat untuk membentuk dan menyusun aturan hukum sesuai nilai-nilai Islam. Kedua, munculnya organisasi masa (ormas) Islam pasca reformasi yang mulai melahirkan kajian nilai-nilai Islam yang dapat mempengaruhi pemerintahan. Atau setidaknya ormasOrmas Islam akan mulai mempraktikkan aturan hukum sesuai syariat diorganisasi dan anggotanya (masyarakat). Ketiga, adanya lembaga pendidikan formal yang memberikan ruang 
untuk mempelajari dan menegakkan nilai-nilai Islam atau syariat Islam. ${ }^{20}$

Penerapan syariat Islam merupakan suatu upaya untuk menjadikan syariat Islam sebagai konstitusi atau peraturan perundang-undangan. Syariat Islam dipahami dengan ketentuan yang telah disyariatkan Allah kepada hamba-Nya. ${ }^{21}$ Konsepsi otonomi daerah memungkinkan dalam penyelenggaraan pemerintahan daerah untuk mengakomodir nilai-nilai kearifan lokal daerah untuk menciptakan ketertiban bagi masyarakat daerah. Ketentuan terhadap pemenuhan nilai-nilai kearifan lokal dalam suatu peraturan daerah disebutkan bahwa dibentuknya peraturan perundang-undangan untuk memenuhi kebutuhan hukum masyarakat dan muatan peraturan daerah menampung kondisi/keadaan daerah. ${ }^{22}$

Kearifan lokal dapat dipengaruhi oleh perilaku-perilaku masyarakat sebagai makhluk sosial. Perilaku sosial masyarakat terbentuk dari nilai keyakinan atau nilai agama yang dapat membentuk kepribadian masyarakat. Oleh karena itu, masuknya nilai-nilai syariat Islam dalam peraturan perundang-undangan, khususnya di daerah, dijamin dengan prinsip demokrasi konstitusional sebagai identitas budaya yang harus diakui dan dihormati oleh orang lain.

Pembentukan peraturan daerah bermuatan syariat Islam merupakan hak pemerintah daerah dan masyarakat daerah yang dijamin konstitusi, dimana dalam penyusunannya diatur melalui Undang-Undang No. 12 Tahun 2011 tentang Pembentukan Peraturan Perundang-Undangan. Dalam penyusunan suatu peraturan daerah, maka materi muatan peraturan daerah dibentuk

\footnotetext{
${ }^{20}$ Jeje Abdul Rajak, "Menyisipkan Politik Hukum dalam Sosialisasi Norma Islam ke dalam Sistem Hukum Nasional", Al-Daulah : Jurnal Hukum dan Perundangan Islam, Volume 7, Nomor 2, (Oktober 2017), 3|3-3।4.

${ }^{21}$ Nur Rohim Yunus, "Penerapan Syariat Islam terhadap Peraturan Daerah dalam Sistem Hukum Nasional Indonesia", Hunafa: Jurnal Studia Islamika, Volume I2, Nomor 2, (20 I 5), 257.

22 Undang-Undang No. 12 Tahun 201 I tentang Pembentukan Peraturan Perundang-undangan. Lihat Bab III Pasal IO Ayat (I) Angka e dan Pasal I4.
} 
dalam rangka penyelenggaraan otonomi daerah dan tugas pembantuan yang menampung kondisi khusus daerah atau penjabaran peraturan perundang-undangan yang lebih tinggi. ${ }^{23}$

Beberapa muatan syariat Islam dalam suatu peraturan daerah dapat dikelompokkan dalam 5 (lima) tingkatan antara lain, pertama terkait al-ahwâl asy-syakhshiyyah yang mengatur hukum keluarga, kedua mengatur urusan ekonomi dan keuangan, ketiga mengatur masalah moralitas dan praktik (ritual) keagamaan, keempat mengatur mengenai penerapan pidana Islam (hudûd, qadzaf dan qishâsh), dan kelima penerapan ideologi Islam. ${ }^{24}$ Dalam prinsip demokrasi konstitusional, pemuatan materil syariat Islam ke dalam peraturan perundang-undangan di daerah selama tidak bertentangan dengan konstitusi merupakan bagian dari demokrasi.

Lahirnya suatu peraturan daerah bermuatan syariat Islam merupakan bagian dari prinsip demokrasi konstitusional yang dianut negara Indonesia. Konstitusi dan prinsip demokrasi dalam konsep rechtsstaat dan rule of law menjadi jaminan dan pengakuan terhadap terselenggaranya peraturan-peraturan daerah yang materil muatannya bersumber dari nilai-nilai agama atau syariat Islam. Dalam praktiknya maka setiap orang wajib menghormati hak masyarakat dan pemerintah daerah dalam rangka tertib kehidupan bermasyarakat, berbangsa dan bernegara.

Pemberlakuan peraturan daerah bermuatan syariat Islam dalam prinsip otonomi daerah merupakan kewenangan pemerintah daerah sesuai dengan ketentuan konstitusi. Dalam pembentukannya, terbentuknya peraturan daerah merupakan otoritas pemerintah daerah atau pemegang kekuasaan. Dengan otoritas yang dimiliki daerah, maka menjadi kewenangan dan tanggung jawab pemerintah daerah untuk mengatur ketertiban masyarakat di daerah. Otoritas menurut Hannah Arendt dapat

\footnotetext{
$23 \mathrm{lbid}$.

${ }^{24}$ Ahmad Mudhar Libbi, dkk. "Analisis Peraturan Daerah perspektif Syariah Islam di Indonesia ditinjau dari Konsep Hak Asasi Manusia", Artikel Ilmiah Hasil Penelitian Mahasiswa, I (I), (Jember: Fakultas Hukum Universitas Jember, 20 I3), 3.
}

\begin{tabular}{l|l}
16 & $\begin{array}{l}\text { al-Daulah } \\
\text { Vol. 8. No. 1. April } 2018\end{array}$
\end{tabular} 
dipahami sebagai sebuah kekuatan yang membuat orang tunduk tanpa harus dibujuk. ${ }^{25}$

Peraturan daerah bermuatan syariat Islam perlu dipahami melalui pendekatan demokrasi secara normatif sebagai suatu aturan yang secara ideal hendak dilakukan atau diselenggarakan oleh pemerintah daerah yang tertuang dalam peraturan daerah sesuai dengan karakteristik masyarakat daerah. Muatan syariat Islam dalam suatu peraturan daerah dapat dikatakan sebagai produk kesepakatan masyarakat yang berarti masyarakat menghendaki ketertiban dalam tatanan masyarakat bersumber pada keyakinan masyarakatnya. Sebagai muslim, syariat Islam merupakan bagian yang tak terpisahkan dalam kehidupan, baik dalam kepentingan pribadi maupun bermasyarakat, berbangsa dan bernegara.

Jaminan prinsip demokrasi konstitusional dalam konsepsi otonomi daerah memberikan kedudukan yang tinggi bagi masyarakat, dimana masyarakat merupakan bagian dari suatu pemerintahan daerah yang tentunya memiliki tradisi, kebiasaan dan adat istiadat yang turut mewarnai sistem pemerintahan daerah, mulai dari bentuk cara berfikir, bertindak dan kebiasaan tertentu dalam kehidupan bermasyarakat. Oleh karena itu, keberadaan peraturan daerah bermuatan syariat Islam menunjukkan prinsip demokrasi konstitusional yang dianut bangsa Indonesia terselenggara sesuai dengan semangat konstitusi.

\section{Peraturan Daerah Bermuatan Syariat Islam: Cita Demokrasi atau Ancaman Demokrasi}

Dengan lahirnya produk hukum atau peraturan daerah yang bermuatan syariat Islam memunculkan pemikiran bahwa peraturan daerah berdasarkan nilai-nilai agama, khususnya syariat Islam, akan memecah belah masyarakat dan melanggar prinsip demokrasi perihal hak asasi manusia di daerah. Peraturan daerah bermuatan

25 Labib Muttaqin, "Positifisasi Hukum Islam dan Formalisasi Syari'ah ditinjau dari Teori Otoritarianisme Khaled Abou El-Fadl", Al-Ihkam, Volume II, Nomor I, (Juni 20 I6), 73. 
syariat Islam dinilai berpotensi memunculkan diskriminasi terhadap pemeluk agama lain. Pemikiran ini, menunjukan terdapat pro dan kontra terhadap peraturan daerah bermuatan syariat Islam dalam konsepsi demokrasi konstitusional. Dimana demokrasi konstitusional, memberikan keleluasaan kepada pemerintah daerah untuk membuat peraturan daerah sesuai dengan muatan lokal atau kebutuhan masyarakat, dan di sisi lain demokrasi tidak membenarkan adanya diskriminasi terhadap hak asasi manusia.

Pembentukan atau pemberlakuan peraturan daerah bermuatan syariat Islam dalam perspektif hak asasi manusia dapat ditinjau melalui dua pendekatan sudut pandang, yaitu

Pertama, pendekatan menggunakan teori kemauan (will theory) yang mengutamakan kemauan pemilik hak dari berbagai keinginan yang berbeda dengan pihak lain. Kedua, dengan pendekatan teori kepentingan (interest theory) yang menekankan bahwa hak berperan untuk melindungi atau mengembangkan kepentingan pemilik hak.26

Hak asasi manusia merupakan ciri dari negara hukum dalam konsep rechtstaat maupun rule of law. Menurut Stahl terdapat empat unsur konsepsi rechtstaat yaitu: (1) hak-hak manusia; (2) pemisahan atau pembagian kekuasaan untuk menjamin hak-hak itu; (3) pemerintah berdasarkan peraturan-peraturan dan (4) peradilan administrasi dalam perselisihan. ${ }^{27}$ Dalam konsepsi tersebut, maka hak setiap manusia memiliki kedudukan yang sangat tinggi yang harus dihargai dan tidak boleh dilanggar oleh orang lainnya.

Dalam praktik pemberlakuan peraturan daerah bermuatan syariat Islam pada satu sisi menunjukkan adanya pengakuan terhadap hak-hak asasi manusia dalam prinsip negara hukum yang demokratis, di sisi yang lain dianggap mendiskriminasi hak-hak asasi manusia yang lainnya. Achmad Bahrur Rozi menggambarkan pemikiran Abdullah Ahmed An-Na'im tentang adanya diskriminasi ketika dilakukannya formalisasi syariat Islam sebagai

26 Majda El-Muhtaj. Hak Asasi Manusia....., 40.

27 Ibid., 23. 
hukum publik, dimana prinsip syariat Islam akan dihadapkan dengan demokrasi secara universal yang berisi cita-cita politik, harapan dan ideologi bangsa. Sehingga konsepsi formalisasi syariat Islam mengarah pada syariat modern yang mengesampingkan konsep syariat secara fundamental. ${ }^{28}$

Berasumsikan pada pendapat Abdullahi Ahmed An-Na'im terkait pergeseran konsep syariat Islam yang fundamental dengan syariat modern menunjukkan adanya prinsip demokrasi konstitusional dalam pembentukan peraturan daerah bermuatan Islam di Indonesia. Di dalam penyelenggaraannya peraturan daerah bermuatan syariat Islam bila merujuk kepada pengelompokan tingkatan formalisasi syariat Islam, seperti al-ahwâl asy-syakhshiyyah, masalah ekonomi dan keuangan, masalah moralitas, penerapan pidana Islam (hudûd, qadzaf dan qishâsh), dan penerapan ideologi Islam. Maka penerapan peraturan daerah bermuatan syariat berdasarkan pada prinsip demokrasi konstitusional di Indonesia hanya terlaksana dalam konsep al-ahwâl asy-syakhshiyyah, hukum keuangan dan ekonomi dan masalah moralitas.

Dengan demikian, demokrasi oleh pemerintah daerah dilaksanakan berlandaskan pada semangat konstitusi atau pembatasan yang meminimalisir terjadinya diskriminasi. Sesuai amanat undang-undang dasar bahwa dalam menjalankan hak dan kebebasannya, setiap orang wajib tunduk kepada pembatasan yang ditetapkan dengan undang-undang dengan maksud semata-mata untuk menjamin pengakuan serta penghormatan atas hak dan kebebasan orang lain dan untuk memenuhi tuntutan yang adil sesuai dengan pertimbangan moral, nilai-nilai agama, keamanan, dan ketertiban umum dalam suatu masyarakat yang demokratis.

Pemberlakuan peraturan perundang-undangan yang bermuatan syariat Islam adalah hak bagi pemerintah daerah maupun masyarakat daerah demi terselenggaranya ketertiban

${ }^{28}$ Achmad Bahrur Rozi, "Penerapan Syari'ath di Negara Modern (Analisis ljtihad Pemikiran Abdullahi Ahmed An-Nailim)", Al-lhkam, Volume 10, Nomor 2, (Desember 20 I5), 364. 
umum yang demokratis. Menjadi kewajiban bagi setiap orang maupun setiap daerah lainnya untuk menghormati hak masyarakat daerah yang menerapkan atau memformalisasi nilai-nilai agama atau syariat Islam ke dalam suatu peraturan daerah sesuai dengan kesepakatan masyarakat daerah.

Dengan merujuk pada demokrasi konstitusional, bahwa pengakuan terhadap hak daerah dan masyarakat daerah dibatasi oleh konstitusi menunjukkan peraturan daerah yang bermuatan syariat Islam bukan suatu ancaman demokrasi. Karena dalam praktiknya pemuatan syariat Islam dalam suatu peraturan daerah harus sesuai dengan ketentuan undang-undang serta tidak diperkenankan bertentangan dengan perturan perundangundangan yang lebih tinggi.

Berangkat dari pemikiran Wheare bahwa peraturan perundang-undangan sebagai resultante (produk kesepakatan), yang berarti bahwa pemerintah bersama masyarakat daerah memiliki hak menjadikan nilai-nilai agama Islam atau syariat Islam sebagai aturan dalam bentuk peraturan daerah. Dengan konsep demokrasi yang digagas oleh Robert Rienow, esensi demokrasi terbentuk dalam pemerintahan otonom. Argumentasi tersebut menggambarkan adanya kebebasan yang diberikan pemerintah kepada pemerintahan daerah yang otonom untuk mengatur urusan dan tugas sebagai pemerintah daerah secara demokratis.

Peraturan daerah bermuatan syariat Islam dalam demokrasi secara normatif merupakan aturan yang secara ideal hendak dilakukan atau diselenggarakan dan menjadi otoritas pemerintah daerah sebagai alat untuk membuat orang atau masyarakat tunduk tanpa harus dibujuk sesuai dengan kepentingan daerah. Pemerintah daerah harus melihat materil atau muatan syariat Islam sebagai kepentingan daerah. Merujuk pada teori kepentingan (interest theory) yang menekankan bahwa hak (pemerintah dan/atau masyarakat daerah) berperan untuk melindungi atau mengembangkan kepentingan pemilik hak yang berdasarkan pada kesepakatan (resultante). Jika peraturan daerah bermuatan syariat 
Islam dipahami dengan pendekatan teori kemauan (will theory) yang mengutamakan kemauan pemilik hak (pemerintah dan/atau masyarakat daerah) dari berbagai keinginan yang berbeda dengan pihak lain, maka akan berdampak pada timbulnya benturan antar kepentingan (conflict of interest).

Terkait dukungan dan tantangan terhadap peraturan daerah bermuatan syariat Islam sebagai bagian demokrasi (cita demokrasi) atau bahkan sebaliknya ancaman demokrasi, perlu menggunakan pendekatan demokrasi dalam perspektif Islam yang dikembangkan pemikir Islam Abdul A'la al-Maududi. ${ }^{29}$ Demokrasi dalam bentuk pengakuan hak asasi manusia dalam Islam menunjukan bahwa tujuan dari hak-hak asasi adalah untuk memberikan kehormatan dan martabat pada manusia dan hak asasi manusia dalam Islam berakar kuat pada keyakinan bahwa Tuhan dan hanya Tuhan sebagai sumber hukum dan sumber semua hak asasi manusia. ${ }^{30}$

Demokrasi memberikan penghormatan atas hak dan kebebasan orang lain yang harus dijaga dalam konsepsi demokrasi yang dibatasi konstitusi (demokrasi konstitusional). Dan seharusnya sebagai negara hukum yang berprinsip demokrasi konstitusional, nilai-nilai syariat Islam bukanlah sebagai ancaman demokrasi, karena syariat Islam memberikan penghargaan terhadap hak asasi manusia sesuai dengan ketentuan syariat Islam.

Dengan pemberlakuan peraturan daerah bermuatan syariat Islam merupakan ciri dari negara demokrasi. Peraturan daerah bermuatan syariat dibentuk sesuai dengan kebutuhan masyarakat dan kesepakatan masyarakat daerah (resultante) serta berlandaskan pada kepentingan (interest). Konsepsi demokrasi dalam perspektif Islam yang menekankan bahwa pemerintah daerah melalui peraturan daerah berperan untuk melindungi atau mengembangkan kepentingan hak masyarakat daerah sesuai syari'at Islam merupakan suatu bentuk dalam memberikan kehormatan dan martabat pada manusia dan hak asasi manusia.

29 Majda El-Muhtaj. Hak Asasi Manusia...., 59.

30 lbid. 


\section{Penutup}

Pemberlakuan peraturan daerah bermuatan syariat Islam merupakan bagian dari prinsip demokrasi dalam konsep negara hukum rechtsstaat maupun rule of law. Konsep rechtsstaat maupun rule of law menggambarkan pengakuan terhadap hak-hak asasi manusia yang mencirikan negara yang demokratis. Dengan dibentuknya peraturan daerah dalam bingkai otonomi daerah menunjukan konsepsi negara hukum diselenggarakan sesuai dengan sistem ketatanegaraan Indonesia yang diatur melalui konstitusi atau Undang-Undang Dasar 1945. Konsepsi negara hukum Indonesia, melahirkan konsepsi demokrasi konstitusional dimana kebebasan dalam melaksanakan tindakan perlu dibatasi oleh konstitusi. Pembentukan peraturan daerah bermuatan syariat Islam merupakan bentuk pengejawantahan prinsip demokrasi konstitusional. Dalam praktiknya, pemberlakuan peraturan daerah bermuatan syariat Islam masih sesuai dengan batas-batas atau ketentuan yang diatur dalam konstitusi maupun undang-undang yang lebih tinggi.

Peraturan daerah bermuatan syariat Islam yang ada di Indonesia bukan suatu ancaman bagi prinsip demokrasi, terlebih demokrasi yang dianut negara Indonesia adalah demokrasi konstitusional, sehingga pemberian kewenangan dan hak untuk mengatur urusan sendiri dalam pemerintahan daerah mengandung prinsip demokrasi yang tidak diperkenankan melebihi batas-batas konstitusi. Dengan dijadikannya syariat Islam sebagai muatan materi peraturan daerah menunjukkan masyarakat secara demokratis menghendaki dan menyepakati produk hukum (resultante) sebagai bagian dari prinsip dan cita demokrasi.

\section{Daftar Pustaka}

Asshiddiqie, Jimly. Hukum Tata Negara dan Pilar-Pilar Demokrasi. Jakarta: Sinar Grafika, 2012. 
Budiardjo, Miriam. Dasar-Dasar Ilmu Politik. Jakarta: Gramedia Pustaka Utama, 2008.

Bik, Alwi. "Peraturan Daerah Syariah Dalam Bingkai Otonomi Daerah". Al-Daulah: Jurnal Hukum dan Perundangan Islam, Volume 3, Nomor 2, (Oktober 2013).

El-Muhtaj, Majda. Hak Asasi Manusia Dalam Konstitusi Indonesia: Dari UUD 1945 Sampai Dengan Amandemen UUD 1945 Tahun 2002. Jakarta: Kencana, 2007.

Fuqoha. "Etika Rangkap Jabatan dalam Penyelenggaraan Negara ditinjau dalam Prinsip Demokrasi Konstitusional". Sawala: Jurnal Administrasi Negara, Volume 3, Nomor 3, (2015).

Libbi, Ahmad Mudhar, dkk. "Analisis Peraturan Daerah perspektif Syariah Islam di Indonesia ditinjau dari Konsep Hak Asasi Manusia". Artikel Ilmiah Hasil Penelitian Mahasiswa, I (1), Jember: Fakultas Hukum Universitas Jember, 2013.

Mahfud, Moh. MD. Politik Hukum di Indonesia. Jakarta: Rajawali Press, 2011.

Muttaqin, Labib. "Positifisasi Hukum Islam dan Formalisasi Syari' ah ditinjau dari Teori Otoritarianisme Khaled Abou ElFadl". Al-Ihkam, Volume 11, Nomor 1, (Juni 2016).

Rajak, Jeje Abdul. “Menyisipkan Politik Hukum dalam Sosialisasi Norma Islam ke dalam Sistem Hukum Nasional". Al-Daulah: Jurnal Hukum dan Perundangan Islam, Volume 7, Nomor 2, (Oktober 2017).

Rosidin, Utang. Otonomi Daerah dan Desentralisasi. Bandung: Pustaka Setia, 2010.

Rozi, Achmad Bahrur. "Penerapan Syariat di Negara Modern (Analisis Ijtihad Pemikiran Abdullahi Ahmed An-Na'im)". Al-Ihkam, Volume 10, Nomor 2, (Desember 2015).

Soekanto, Soerjono dan Sri Mamudji. Penelitian Hukum Normatif. Jakarta: Rajawali Press, 2006.

Sunarno, Siswanto. Hukum Pemerintahan Daerah di Indonesia. Jakarta: Sinar Grafika, 2012. 
Syafa'at, Nur. "Pelayanan Kesehatan di daerah Otonom Baru (Studi Kasus di Kabupaten Tana Tidung, Kalimantan Timur)". Sawala: Jurnal Administrasi Negara, Volume 4, Nomor 1, (2016).

Yunus, Nur Rohim. "Penerapan Syariat Islam terhadap Peraturan

Daerah dalam Sistem Hukum Nasional Indonesia". Hunafa: Jurnal Studia Islamika, Volume 12, Nomor 2, (2015).

Peraturan Presiden No. 87 Tahun 2014 tentang Peraturan Pelaksana Undang-Undang No. 12 Tahun 2011 tentang Pembentukan Peraturan Perundang-Undangan.

Undang-Undang Dasar 1945.

Undang-Undang No. 12 Tahun 2011 tentang Pembentukan Peraturan Perundang-undangan.

Undang-Undang No. 23 Tahun 2014 tentang Pemerintahan Daerah. 